\title{
New records of Polyporivora picta (Meigen, 1830) from the Czech Republic and Greece with notes on its larval biology and distribution in Europe (Diptera: Platypezidae)
}

Michal Tkoč

New records of Polyporivora picta (Meigen, 1830) from the Czech Republic and Greece with notes on its larval biology and distribution in Europe (Diptera: Platypezidae). - Čas. Slez. Muz. Opava (A), 60: 263-267, 2011

\begin{abstract}
Two new records of flat-footed fly Polyporivora picta (Meigen, 1830) (Diptera: Platypezidae) in the Czech Republic and Greece are documented. The distribution of this species in Europe is reviewed based on published records as well as new records presented here. The distributional map of Europe is presented. Larval biology of Polyporivora picta (Meigen, 1830) and rearing made from host fungus Trametes versicolor (L.) Lloyd. is commented and debated. The phenomenon of recent rediscovery of this species in Central and South Europe is discussed.
\end{abstract}

Keywords: Diptera, Platypezidae, Polyporivora picta, Trametes versicolor, larva, puparium, faunistics, biology, distribution, Czech Republic, Greece

\section{Introduction}

Flat-footed fly Polyporivora picta (Meigen, 1830) seems to be scarce in Central and South Europe, but not so in north European countries, where is rather common (Chandler 2001). This species is known in Central Europe from 4 countries: Germany, Poland, Hungary and Slovakia (Chandler 2001, 2007). It has not been recorded in Austria yet. In Slovakia, P. picta was firstly found in 1866, in Losoncz (= Lučenec) by Kowarz (1867), who published it under the synonym Platypeza superba Kowarz. Then this species was rediscovered in Slovakia in 2010 by Roháček \& Ševčík (2011) after more than 140 years.

Till now, Polyporivora picta has not been found in the Czech Republic, although the Czech and Slovak fauna of Platypezidae was studied intensively in the last years (Vaňhara 1980, 1982, 1984, 1986, 1995). Furthermore, there were several extensive Czech and Slovak dipterological surveys dealing also with Platypezidae (Vaňhara \& Roháček 1995; Vaňhara 1998; Vaňhara \& Barták 2000; Vaňhara, Barták \& Kubík 2005; Tkoč \& Vaňhara 2008; Roháček \& Ševčík 2009), in which this conspicuous species was not found as well. The distribution in Europe is summarized by Chandler $(2001,2007)$ together with other relevant information about this species. Also two similar rearings from the Czech Republic were carried out in 2002 and 2006 (Ševčík 2010) from fungus Trametes versicolor (L.) Lloyd., but only the more common species Polyporivora ornata (Meigen, 1838) was reared.

The immature stages of Polyporivora picta are fungivorous, regular fungus host is Trametes versicolor, where they live in the tissue of fruiting body without having cocoon, in contrast with species Polyporivora ornata (Meigen, 1838). They overwinter as larva and the adult has an autumnal flight period from late IX to mid X (Chandler 2001).

The first observation of Polyporivora picta in the Czech Republic was made by Petr Bílek (pers. comm., 14. XI. 2009, Natural Monument Na Plachtě close to Hradec Králové), who photographed one female, but no material was collected for the study. In this paper, I give the first record of $P$. picta from the Czech Republic (obtained by means of rearing from the fungus Trametes versicolor) and from Greece (Malaise trap).

\section{Material and methods}

The Czech material of adult flies recorded in this study was reared under laboratory conditions. The rearing

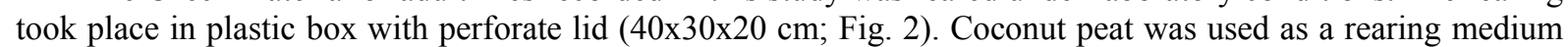


and the humidity in the box was regulated by sprayer when the medium was too dry. The temperature was 10 $18{ }^{\circ} \mathrm{C}$ and the box was not exposed to the direct sunlight. Greek material was caught by Malaise trap. Flat-footed fly material was identified by the author and is now deposited in the National Museum in Prague as well as the parasitoid wasp material. Ján Macek identified the parasitoid wasp. The determination of host fungus was confirmed by mycologist Daniel Dvoŕák (Masaryk University, Brno). The nomenclature used here follows Chandler (2001).

\section{Polyporivora picta (Meigen, 1830)}

\section{Material}

Czech Republic, Moravia: Chřiby Natural Park, Buchlovice, Dlouhá řeka near Smrad'avka (Fig. 3), $290 \mathrm{~m}$

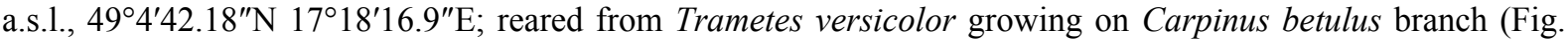
4); fungus with larvae collected: 16.i.2011, adults reared: 21.iii.2011: $2 \hat{\jmath} \hat{\partial}, 27$. iii.2011: $2 \hat{\jmath} \hat{\sigma}, 3$. iv.2011: $5 \hat{\partial}$,

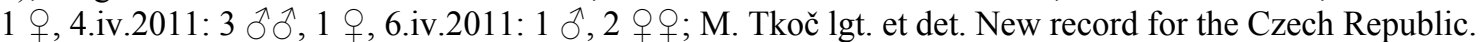

Greece: Vironia village, Beabies Site, vicinity of the Kerkini lake, $1150 \mathrm{~m}$ a.s.1., $41^{\circ} 19^{\prime} 15.4^{\prime \prime} \mathrm{N} 23^{\circ} 13^{\prime} 39.6^{\prime \prime} \mathrm{E}$; Natural mixed beech and spruce forest near the stream Sultanitsa. Malaise trap; 3-9.xi.2008, 1 O; G. Ramel lgt., M. Tkoč det. New record for Greece.

\section{Distribution}

Polyporivora picta is an European species, more abundant in northern part of Europe (Great Britain and Fennoscandia) but rare in Central Europe and missing in Mediterranean region. The map of distribution is based on Chandler (2001) and other published records (see Fig. 1). Italian record in Chandler $(2001,2007)$ is given erroneously: there is no record of $P$. picta in the Italian check-list (Raspi 1995), it was probably confused with Polyporivora ornata. P. picta was recently found also in Portugal (Ebejer \& Andrade 2010), which makes their record to be the second southernmost after the Greece record published here. The northern border of distribution probably correlates with Arctic Circle, when the northernmost record from 1821 of Zetterstedt (1838) is taken to the account.

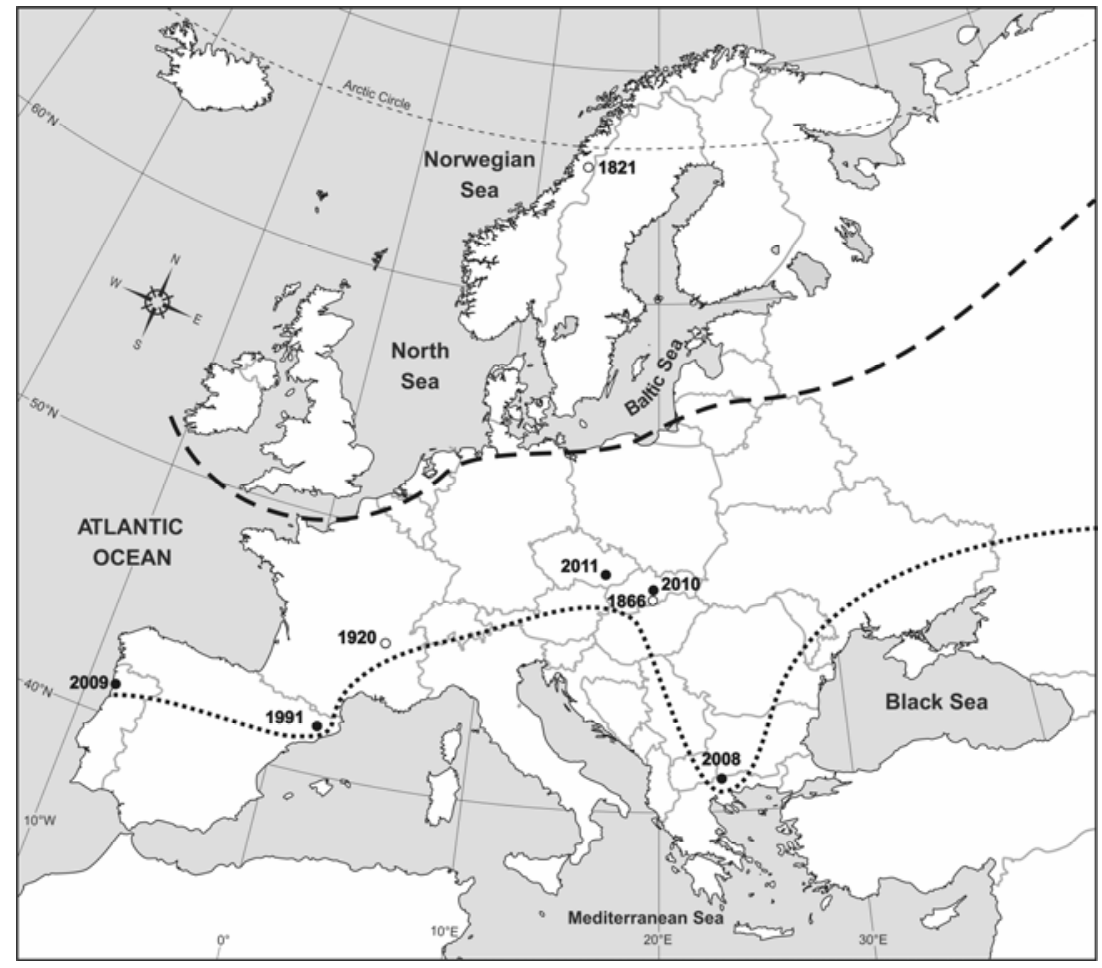

Fig. 1: Distribution of Polyporivora picta (Meigen, 1830) in Europe. Based on Chandler (2001) and other published records (1821: Zetterstedt (1838); 1866: Kowarz (1867); 1920: Bonnamour (1925); 1991: Carles-Tolrá (1999); 2008: Tkoč - this paper; 2009: Ebejer \& Andrade (2010); 2010: Roháček \& Ševčík (2011); 2011: Tkoč this paper). Dashed line: southern border of common distribution. Dotted line: southern border of distribution. $\circ$ : historical records. $\bullet$ : recent records. 


\section{Larval biology}

Polyporivora picta larvae develop in the bracket fungus Trametes versicolor. In the current rearing no cocoon was present around the larval body. The larva is burrowed inside the tissue (Fig. 6) of fruiting bodies of T. versicolor (Fig. 5). When the host fungus is greatly infested with larvae, there could be 20-40 individuals in one fruiting body. Infested fruiting bodies were found in 16.i.2011 with larvae of last instars and some larvae in lower instars, but their quantity was low (about $10 \%$ ). The sampling site (Fig. 3) was visited also in March and April of 2011, but surprisingly there were neither larvae nor puparia inside of the $T$. versicolor tissue anymore. This is evidence that $P$. picta overwinter as a larva in the host fungus, then it leaves the fungus before pupation (ii.-iv. in $\mathrm{CZ}$ ) and pupates in the soil. In the laboratory conditions the emerging of adults took place between 21.iii.-6.iv. During these 17 days 17 adult flies (Fig. 8) has been reared, and there were approximately 200-400 larvae (Fig. 7) in the beginning of this rearing, thus the success rate was between 4.25 and $8.5 \%$. There were also many (more than one hundred) parasitoid wasp specimens observed during the rearing in the plastic box. Two males and two females of them were preserved and recognized as Tersilochus sp. (Hymenoptera: Ichneumonidae).

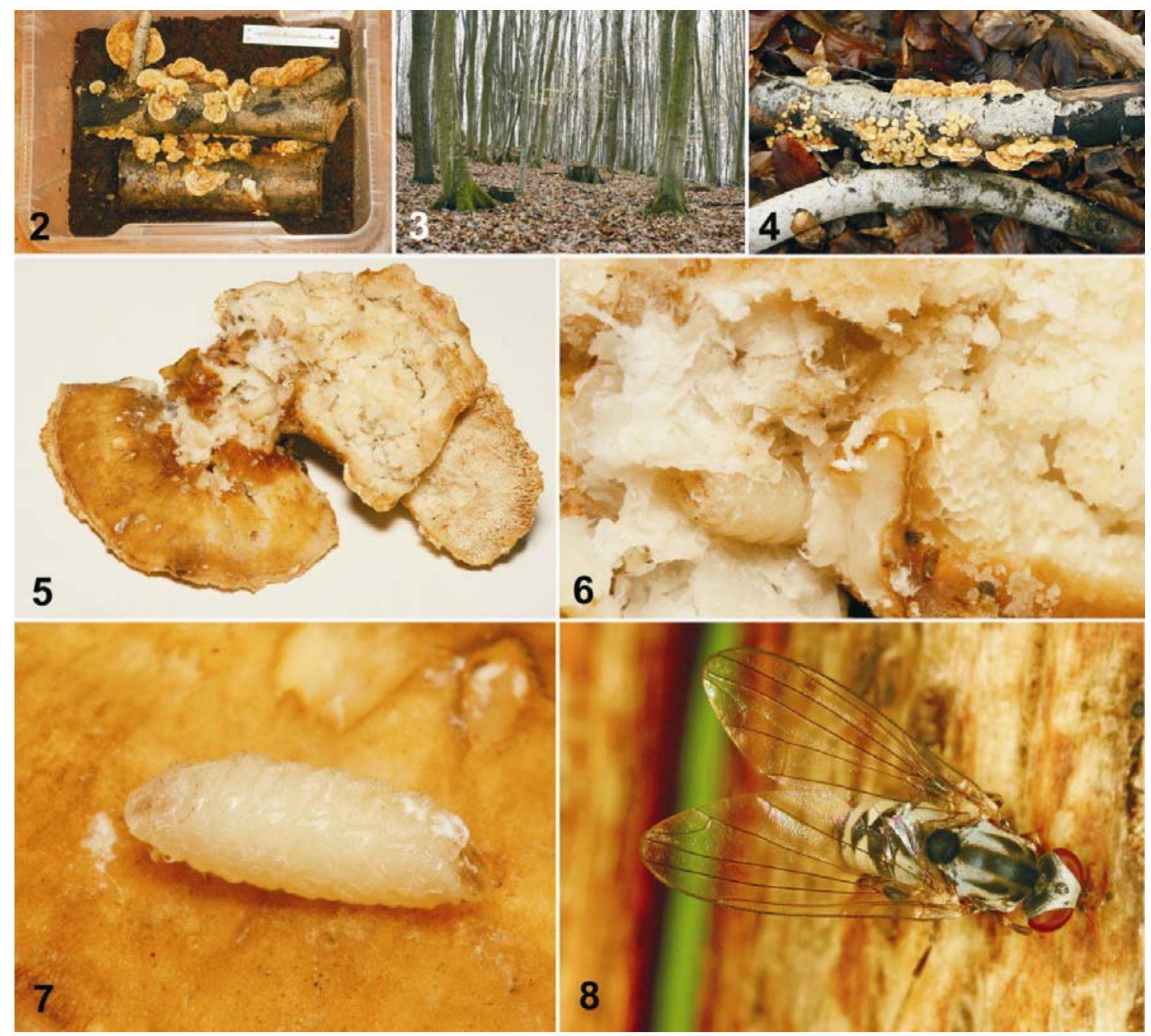

Figs 2-8: Polyporivora picta (Meigen, 1830), rearing, habitat, host fungus, larva and adult: 2 - rearing box; 3 sampling locality Dlouhá řeka in CZ in January; 4 - trunks overgrown with fruiting bodies of Trametes versicolor; 5 - fruiting body of Trametes versicolor with larva; 6 - detail of larva burrowed inside mycelium of Trametes versicolor; 7 - larva in detail; 8 - adult female from Gemer Region (Slovakia, 2010). Photos by M. Tkoč (Figs 2-7) and J. Roháček (Fig. 8). 


\section{Discussion and conclusions}

Polyporivora picta is a conspicuous species of flat-footed fly, easily distinguishable according to its typical colour pattern in females. The southern border of its distributional range more or less correlates with the northern border of Mediterranean region, but additional recent records are needed to evaluate its distribution more precisely.

From Europe, autumnal flight period of adults is reported (Chandler 2001), which is probably the case of other remaining individuals left on the sampling site (CZ). I believe that early emergence of adults was influenced by the laboratory conditions in this case, whereas under natural conditions the pupation would be longer and the adults would emerge later (viii.-xi.).

There still remain a question, why there are so many recent records of Polyporivora picta and the only remaining records are 90-190 years old. In this case it is most probably caused by higher attention dedicated to this species by scientists nowadays. It could also be consequence of some climate change in Europe, but since the historical record is incomplete and scarce, it is not possible to make any significant conclusions based on this phenomenon.

Acknowledgements: I thank Mr. Gordon Ramel for providing the material from Greece, Daniel Dvořák for the fungus redetermination and Jindřich Roháček for the photo of adult $P$. picta he kindly provided to me. I am also indebted to Ján Macek for the parasitoid wasp identification. I also thank Jan Ševčík for his helpful review of the manuscript. This work was supported by grant from the Ministry of Culture MK00002327201 (to National Museum, Prague) and by the student grant SVV-2012 (Charles University, Prague).

\section{References}

Bonnamour S. (1925): Les insects parasites des champignons. - Annales Soc. Linn. II., 72: 85-93.

Carles-Tolrá M. (1999): Dípteros nuevos e interesantes para la Península Ibérica e Islas Baleares (Diptera: Xylomyidae, Stratiomyidae, Acroceridae, Scenopinidae, Lonchopteridae, Opetiidae, Platypezidae, Conopidae). - Boletín de la S. E. A., 23(1-2): 195-212.

Chandler P. J. (2001): The Flat-footed Flies (Diptera: Opetiidae, Platypezidae) of Europe. Fauna Entomologica Scandinavica, Vol. 36, 276 pp., E. J. Brill, Leiden - Boston - Köln.

- (2007): Platypezidae. In Pape T. (ed.): Fauna Europaea: Diptera, Brachycera. Fauna Europaea, Version 1.3. http://www.faunaeur.org.

Ebejer M. \& Andrade R. (2010): First Records of Platypezidae (Diptera) from Mainland Portugal with a First Record for Iberia of the Genus Paraplatypeza Kessel \& Magioncalda. - Boletín de la S. E. A., 47: 454.

Kowarz F. (1867): Beschreibung sechs neuer Dipteren-Arten. - Verh. Zool.-Bot. Ges., 17: 319-324.

Raspi A. (1995): Platypezidae. In Belcari A. \& Munari L.(eds): Fascicolo 70. Dipera Platypezoidea, Syrphoidea. In Minelli A., Ruffo \& La Posta S. (eds): Checklist delle specie della fauna Italiana. Pp. 5-6. Edizione Calderini, Bologna.

Roháček J. \& Ševčík J. (2009): Platypezidae. In Roháček J. \& Ševčík J. (eds): Diptera of the Pol’ana Protected Landscape Area - Biosphere Reserve (Central Slovakia). 340 pp. (pp. 150-155), SNC SR, Administration of the PLA - BR Pol'ana, Zvolen.

- (2011): The fauna of Opetiidae and Platypezidae (Diptera) in the Gemer region (Central Slovakia). - Čas. Slez. Muz. Opava (A), 60: 41-47.

Ševčík J. (2010): Czech and Slovak Diptera associated with fungi. 112 pp., Slezské zemské muzeum. Opava.

Tkoč M. \& Vaňhara J. (2008): Opetiidae and Platypezidae (Diptera) of the Jizerské hory Mts and Frýdlant region. In: Diptera Jizerských hor. Diptera of the Jizerské hory Mts. Sbor. Severočes. Muz. - Př́r. Vědy, Liberec, 26: 255-260.

Vaňhara J. (1980): Species composition and biology of the family Platypezidae (Diptera) in Czechoslovakia, with regard to its occurrence in a lowland forest. In Chvála M. (ed.), Dipterologica bohemoslovaca. Vol. 2. Acta Univ. Carol., Biol., 429-436.

- (1982): The Moravian species of flat-footed flies (Diptera, Opetiidae and Platypezidae). In Rozkošný R. \& Vaňhara J. (eds), Dipterologica bohemoslovaca. Vol. 3. Folia Fac. Sci. Nat. Univ. Purk. Brun., 23, Biol., 74: 137-142.

- (1984): The Bohemian species of flat-footed flies (Diptera, Opetiidae and Platypezidae). - Čas. Nár. Muz., ‘̆. přírod., 153: 61-63.

- (1986): The flat-footed flies (Opetiidae and Platypezidae, Diptera) in a lowland forest. In Olejníček J. \& Spitzer K. (eds), Dipterologica bohemoslovaca. 214 pp. (79-84 pp.). Jihočes. muz., přír. vědy (4). České 
Budějovice.

- (1995): Recent distribution of flat-footed flies (Diptera: Opetiidae and Platypezidae) in Czech and Slovak Republics with a revised check list and species quality indexing. - Čas. Slez. Muz. Opava (A) 44: 43-61.

- (1998): Opetiidae and Platypezidae. In Rozkošný R. \& Vaňhara J. (eds), Diptera of the Pálava Biosphere Reserve of UNESCO. I., 219 pp. (187-190 pp.), Folia Fac. Sci. Nat. Univ. Masaryk. Brun., Biol. (99), Brno.

- (2009): Platypezidae Fallén, 1815. In Jedlička L., Stloukalová V. \& Kúdela M. (eds): Checklist of Diptera of the Czech Republic and Slovakia. Electronic version 2. <http://zoology.fns.uniba.sk/diptera2009> + CD-ROM: ISBN 978-80-969629-4-5.

Vaňhara J. \& Barták M. (2000): Platypezidae. In Barták M. \& Vaňhara J. (eds), Diptera in an Industrially Affected Region (North-Western Bohemia, Bílina and Duchcov Environs). Vol 1. 240 pp. (pp. 203-211), Folia Fac. Sci. Nat. Univ. Masaryk. Brun., Biol., Brno.

Vaňhara J., Barták M. \& Kubík Š. (2005): Platypezidae. In Barták M. \& Kubík Š. (eds), Diptera of Podyjí National Park and its Environs. 434 pp. (pp. 183-186). Česká zemědělská univerzita v Praze, Praha.

Vaňhara J. \& Roháček J. (1995): Opetiidae, Platypezidae. In Roháček J., Starý J., Martinovský J. \& Vála M. (eds): Diptera Bukovských vrchov [Diptera of the Bukovské hills]. 232 pp. (pp. 98-99), SAŽP Správa CHKO a BR Východné Karpaty, Humenné.

Zetterstedt J. W. (1838): Dipterologis Scandinaviae - Sect. 3: Diptera. In Zetterstedt J. W.: Insecta Lapponica, 1139 pp. (pp. 477-868), Lipsiae.

\section{Nové záznamy druhu Polyporivora picta (Meigen, 1830) z České Republiky a Řecka s poznámkami o jeho larvální biologii a rozš́í̌ení v Evropě (Diptera: Platypezidae)}

Jsou podány dva nové faunistické záznamy druhu Polyporivora picta (Meigen, 1830) (Diptera: Platypezidae) v České Republice a Řecku. Dále je ve článku vyhodnoceno rozšřření tohoto druhu v Evropě na základě publikovaných záznamů a take nových záznamů publikovaných zde. Je zde prezentována mapa rozšíření v Evropě. Nález z Řecka představuje nejjižnější záznam tohoto druhu v Evropě. Larvální biologie druhu Polyporivora picta (Meigen, 1830) a další podrobnosti o chovu z plodnic houby Trametes versicolor (L.) Lloyd. jsou vyhodnoceny a debatovány. Je zde take diskutován fenomém nedávného znovuobjevení tohoto druhu ve střední a jižní Evropě.

Author's address: Michal Tkoč, Dept. of Entomology, National Museum, Kunratice 1, CZ-148 00 Praha 4 \& Dept. of Zoology, Faculty of Science, Charles University in Prague, Viničná 7, CZ-128 44 Praha 2, Czech Republic. E-mail: michaltkoc@gmail.com 